JOTE Volume 2 Nomor 1 Tahun 2020 Halaman 75-81

JOURNAL ON TEACHER EDUCATION

Research \& Learning in Faculty of Education

\title{
MENIGKATKAN HASIL BELAJAR BIOLOGI MENGUNAKAN METODE CIRC (Cooperative Integrated Reading and Composition) BERBASIS HERBARIUM
}

\author{
Nur Rizkiyah \\ Program Studi Pendidikan Biologi Universitas Indraprasta PGRI Jakarta
}

Email : gyetaman@yahoo.com

\begin{abstract}
Abstrak
Tujuan penelitian ini mendeskripsikan hasil belajar siswa dengan menggunakan Metode pembelajaran CIRC (Cooperative Integrated Reading and Composition) berbasis Herbarium pada konsep Pteridophyta di kelas X SMA Negeri 4 Bojonegoro. Hasil wawancara guru mata pelajaran dengan siswa kelas $\mathrm{X}$, untuk konsep tumbuhan paku mereka menemui kesulitan untuk memahaminya. Salah satu model pembelajaran yang digunakan untuk mengatasi kesulitan tersebut adalah $C I R C$ berbasis herbarium. Herbarium yang digunakan adalah jenis-jenis tumbuhan paku yang dikumpulkan siwa selama masa praktikum lapangan dengan teknik menjelajah dan sebagian ditambah dengan koleksi milik guru yang sudah ada. Jenis penelitian yang digunakan dalam penelitian ini adalah penelitian kualitatif dengan tipe penelitian tindakan kelas yang dilaksanakan di kelas X SMAN 4 Bojonegoro melalui dua siklus. Data dikumpulkan dengan menggunakan hasil tes, observasi kelas dan angket siswa. Hasil penelitian ini menunjukan dengan menggunakan metode pembelajaran CIRC berbasis herbarium maka hasil belajar biologi siswa dapat ditingkatkan. Hal ini terlihat dari hasil tes awal mencapai $24 \%$ hasil tes akhir siklus I mencapai $52 \%$ pada siklus II meningkat menjadi 84\%. Hasil angket siwa terhadap metode pembelajaran CIRC berbasis herbarium ysng digunakan pada konsep tumbuhan paku menunjukan bahwa sebagian besar siswa sangat setuju pembelajaran ini menggunakan pendekatan herbarium.
\end{abstract}

Kata kunci: Metode Pembelajaan CIRC (Cooperative Integrated Reading and Composition), Hasil belajar, konsep ptheridophyta.

\begin{abstract}
The purpose of this study was to describe student learning outcomes using the Herbarium-based CIRC (Cooperative Integrated Reading and Composition) learning method on the Pteridophyta concept in class X SMA Negeri 4 Bojonegoro. The results of the subject teacher interviews with class $X$ students, for the concept of ferns they found it difficult to understand. One of the learning models used to overcome these difficulties is herbarium-based CIRC. The herbarium used is the types of ferns that the students collected during the field practicum with exploring techniques and partially added to the existing teacher's collection. This type of research used in this research is qualitative research with the type of classroom action research conducted in class X SMAN 4 Bojonegoro through two cycles. Data were collected using test results, classroom observations and student questionnaires. The results of this study indicate that by
\end{abstract}


using the herbarium-based CIRC learning method, students' learning outcomes of biology can be improved. This can be seen from the initial test results reaching $24 \%$, the final test results of the first cycle reached $52 \%$ in the second cycle increasing to $84 \%$. The results of the student's questionnaire on the herbariumbased CIRC learning method used in the concept of ferns showed that most students strongly agreed that this learning used the herbarium approach.

Keywords: Herbarium Approach CIRL, Learning Outcomes, Pthheridophyta Concept

\section{PENDAHULUAN}

Guru mempunyai tanggung jawab penuh untuk menarik minat siswa terhadap mata pelajaran biologi serta mampu meningkatkan hasil belajar, dalam hal ini proses interaksi harus berjalan dengan maksimal. Persoalannya adalah bagaimana kita dapat membelajarkan materi biologi dengan sebaik baiknya pada siswa. Hal tersebut selalu menjadi bahan kajian bagi pelaku pendididkan dalam menemukan model pembelajaran yang baik dan pengunaan media pembelajaran yang sesuai dengan materi yang di ajarkan. Pendekatan pembelajaran sangat penting diterapkan guna menjadikan siswa lebih kreatif dan dapat meningkatkan aktifitas siswa untuk dapat berinteraksi d dan juga meningkatkan minat siswa untuk menyampaikan ide atau gagasannya dalam mengikuti pelajaran (Slameto 1995:99). Pembelajaran yang dapat memberikan waktu dan melibatkan siswa untuk belajar adalah pembelajaran Cooperative Integrated Reading and Composition (CIRC). Metode ini adalah proyek kelompok yang dilaksanakan dalam jangka waktu tertentu. Melibatkan para siswa dalam desain kelompok, penyelidikan,pemecahan masalah, atau pengalaman yang memberi perluasan waktu kepada para siswa untuk bekerja secara otonom merupakan ciri khas yang dimiliki oleh model pembelajaran ini (Irawadi, M. H,dkk : 2015).

Pendekatan pembelajaran ini salah satunya menekankan kepada bagaimana belajar di skolah yang dikontekskan ke dalam situasi dunia nyata, sehingga hasil belajar dapat diterima dan berguna bagi siswa selama di sekolah atau setelah mereka lulus dari sekolah tersebut. Pendekatan pembelajaran tersebut adalah pendekatan pembelajaran yang didasarkan kepada pembelajaran kontekstual. Penerapan pembelajaran kontekstual ini diharapkan dapat mendorong minat, motivasi, dan keaktifan siswa dalam proses KBM, yang pada akhirnyan dapat meningkatkan hasil belajar siswa secara optimal (Darsono 2001:50) Hakekat pembelajaran kontekstual ini adalah pembelajaran yang menekankan aspek-aspek REACT, yaitu aspek mengaitkan (relating), aspek mengalami (experiencing) aspek menerapkan teori pada situasi tertentu (applying) aspek kerja sama (cooperating), dan aspek perolehan pengetahuan baru (transferring). Aspek-aspek tersebut merupakan aspek-aspek pokok pada pembelajaran IPA sebagai proses (Darsono, 2001:55)

Observasi awal yang peneliti lakukan pada guru bidang studi biologi yang mengajar di kelas X SMA Negeri Bojonegoro, peneliti mendapat informasi bahwaprestasi belajar siswa kelas $X$ untuk materi tumbuhan paku (Pteridophyta) masih rendah, hsl ini didasarkan pada hasil ulangan hariaqn dengan total nilai rata-rata secara klasikal menunjukan nilai yang masih rendah yakni sebesar 62,50. Peneliti juga mendapatkan informasi bahwa guru masih menggunakan 
metode dan pendekatan pembelajaran yang konvensional sehingga situasi belajar hanya berfokus pada guru, siswa tidak memiliki kesempatan untuk berkreatifitas.

Untuk konsep tumbuhan paku, siswa merasa sangat sulit mempelajarinya terutama untuk sup pokok bahasan seperti ciri-ciri tubuh tumbuhan paku dan daur hidup tumbuhan paku serta klasifikasinya. Hasil wawancara guru mata pelajaran dengan siswa kelas $\mathrm{X}$, untuk konsep tumbuhan paku mereka menemui kesulitan untuk memahaminya, hal ini disebabkan karena istilah pada proses metagenesis tumbuhan paku sangat sulit dipahami siswa, siswa pun sulit mengklasifikasi jenis tumbuhan paku. Hal inilah mendorong penulis untuk mencoba mempraktekan metode pembelajaran terbaru hasil temuan penulis sehingga proses pembelajaran berjalan dengan efektif dan hasilnya sangat memuaskan. Salah satu metode yang digunakan adalah metode CIRC (Cooperative integrated Reading and Composition) berbasis herbarium yang digunakan untuk identifikasi dan klasifikasi, serta pemahaman konsep-konsep penting terhadap tumbuhan paku. Herbarium yan digunakan adalah jenis-jenis tumbuhan paku yang dikumpulkan siswa selama masa praktikum lapangan dengan teknik menjelajah ditambah dengan herbarium koleksi guru. Berdasarkan uraian di atas maka penulis tertarik untuk mengadakan penelitian dengan judul Meningkatkan hasil belajar Siswa dengan Menggunakan Metode CIRC (Cooperative Integrated Reading and Composition) berbasis Herbarium pada Konsep Pteridophyta di kelas X SMA Negeri 4 Bojonegoro

Berdasarkan latar belakang maka dapat diidentifikasi permasalahan sebagai berikut : Apakah penggunaan metode pembelajaran CIRC (Cooperative Integrated Reading and Composition) berbasis Herbarium dapat meningkatkan hasil belajar biologi pada konsep Pteridophyta di kelas X SMA Negeri 4 Bojonegoro? Tujuan penelitian ini adalah untuk mendeskrisikan Metode pembelajaran CIRC (Cooperative Integrated Reading and Composition) berbasis Herbarium pada konsep Pteridophyta untuk meningkatkan hasil belajar siswa kelas X SMA Negeri 4 Bojonegoro

\section{METODE}

Jenis penelitian yang digunakan dalam penelitian ini adalah penelitian kualitatif dengan tipe penelitian tindakan kelas (Class Action Resesrch). Penelitian tindakan kelas (PTK) adalah penelitian yang dilakukan oleh guru di kelas melalui refleksi diri dengan tujuan untuk memperbaiki kinerjanya sebagai guru, sehingga hasil belajar siswa menjadi meningkat (Manurung, 2008). Penelitian tindakan kelas ini dilaksanakan dalam dua siklus. Satu siklus terdiri dari perencanaan, pelaksanaan tindakan, pengamatan, dan refleksi.

Penelitian ini berlokasi di SMA Negeri 4 Bojonegoro. Penelitian ini berlangsung selama 1 bulan yaitu pada bulan Maret 2015. Variabel yang penulis gunakan dalam penelitian ini adalah variable bebas yaitu metode pembelajaran CIRC (Cooperative Integrated Reading and Composition) berbasis Herbarium serta variable terikat yaitu hasil belajar Biologi.

Adapun instrument yang digunakan dalam penelitian ini adalah tes hasil belajar untuk memperoleh data tentang hasil belajar siswa setelah menerapkan 
Metode Pembelajaran CIRC (Cooperative Integrated Reading and Composition) berbasis Herbarium, lembar observasi untuk mengamati aktifitas siswa, angket siswa yang digunakan siswa untuk bahan refleksi, lembar catatan tindakan guru pada saat kegiatan penerapan Metode Pembelajaran CIRC (Cooperative Integrated Reading and Composition) berbasis herbarium dalam kegiatan pembelajaran.

Teknik analisis data hasil penelitian ini akan diolah dengan menggunakan analisis data kuantitatif dan analisis data Kualitatif (Arikunto, 2001) Data kuantitatif yang terkumpul berupa angka yang terdiri dari skor nilai tes awal dan tes akhir belajar persiklus, dianalisis dengan menggunakan statistic depkriptif. Maka untuk menghitung presentasi dari skor yang dicapai setiap siswa dalam tes secara keseluruhan prosentase dan data kualiitatif dianalisis dengan mengikuti tiga tahapan yaitu : reduksi data, penyajian dan pemaparan data, dan penarikan kesimpulan.

\section{HASIL DAN PEMBAHASAN}

Sebelum penelitian ini dilakukan, peneliti melakukan Observasi awal dan wawancara singkat dengan guru mata pelajaran Biologi. Dari hasil wawancara dan observasi menunjukan bahwa hasil belajar biologi siswa khusus kelas $X$ masih tergolong rendah dan model pembelajaran yang diterapkan selama ini adalah model pembelajaran konvensional, sehingga kurang berhasil meningkatkan hasil belajar biologi siswa.

Selanjutnya, peneliti mengadakan tes awal kepada siswa kelas $\mathrm{X}-1$, SATU Minggu sebelum Metode Pembelajaran CIRC (Cooperative Integrated Reading and Composition) berbasis herbarium diterapkan. Tes awal ini dilakukan untuk mengetahui kemampuan awal siswa terhadap konsep tumbuhan paku (Pteridophyta). Nilai tes awal juga dijadikan acuan untuk mengetahui peningkatan hasil belajar biologi siswa setelah diterapkan Metode Pembelajaran CIRC (Cooperative Integrated Reading and Composition) berbasis herbarium. Soal soal tes awal berupa materi yang berhubungan dengan materi yang akan diajarkan. Dari hasil tes awal, menunjukan bahwa terdapat 8 siswa dengan potensi ketuntasan sebesar $24 \%$ yang mencapai nilai $>75 \%$. Hal ini member gambaran bahwa hasil belajar biologi siswa kelas $\mathrm{X}-1$ pada konsep tumbuhan paku masih tergolong rendah.

Bertolak dari hasil reflksi awal, maka peneliti, guru mata pelajaran, dan teman sejawat merancang kegiatan lanjutan sesuai tahap-tahap siklus dengan Metode Pembelajaran CIRC (Cooperative Integrated Reading and Composition) berbasis herbarium, agar dapat meningkatkan hasil belajar siswa. Tes akhir siklus I menunjukan bahwa sebanyak 18 orang siswa atau $52 \%$ mencapai nilai dengan presentasi ketuntasan $>75 \%$. Hal ini menunjukan bahwa pada siklus pertama sudah mengalami peningkatan tetapi belum mencapai indicator pembelajaran yang ditetapkan. Hasil terakhir tindakan siklus I. hasil tes akhir siklus II menunjukan bahwa sebanyak 29 orang siswa atau sebesar $84 \%$ siswa mencapai nilai dengan presentasi ketuntasan $>75 \%$. Ini menunjukan terjadi peningkatan hasil belajar oleh siswa. Secara umum, ada dua siklus yang digunakan peneliti dalam penelitian tindakan kelas dengan Metode Pembelajaran 
CIRC (Cooperative Integrated Reading and Composition) berbasis herbarium. Setiap siklus terdiri dari dua kali pertemuan dan pada akhir pertemuan dilakaukan tes akhir secara individu. Sebelum penelitian ini dilakukan, peneliti melakukan tes awal kepada setiap siswa untuk mengetahui penguasaan siswa terhadap konsep tumbuhan paku sebelum menerapkan pendekatan herbarium.

Pada siklus I, tindakan yang dilakukan berdasarkan rencana yang disusun pada saat perencanaan. Kegiatan pembelajaran dilaksanakan dengan menggunakan Metode Pembelajaran CIRC (Cooperative Integrated Reading and Composition) berbasis herbarium. Perolehan siswa berdasarkan ketuntasan belajar mencapai $52 \%$ atau sebanyak 18 siswa yang memperoleh nilai dengan presentasi ketuntasan $>75 \%$. erdasarkan hasil observasi pada siklus I sebagian guru dan siswa telah melakukan sebagian kegiatan pembelajaran dengan menggunakan Metode Pembelajaran CIRC (Cooperative Integrated Reading and Composition) berbasis herbarium, tetapi masih banyak terdapat kekurangan baik dari guru maupun dari siswa. Kekurangan yang berasal dari guru adalah guru belum menguasai seluruh scenario yang ada pada RPP dengan baik, guru kurang memberikan motivasi secara baik kepada siswa, motivasi hanya diberikan pada saat persiapan dan akhir pembelajaran.

Guru belum memberikan bimbingan secara merata kepada setiap kelompok. Guru belum mengatur waktu belajar dengan baik, sehingga ada kelompok yang belum menyelesaikan identifikasi tumbuhan paku. Sedangkan kekurangan yang terdapat pada siswa adalah Metode Pembelajaran CIRC (Cooperative Integrated Reading and Composition) berbasis herbarium merupakan hal baru bagi siswa sehingga siswa masih merasa kaku dalam proses pembelajaran, siswa masih maengutamakan penonjolan individu, timbulnya prilaku yang kurang relevan dari siswa yang bererita, bermain dan saling mengganggu.

Melihat kekurangan yang ada pada siklus I dan hasil belajar siswa yang belum mencapai indicator yang ditentukan maka guru, peneliti dan teman sejawat memutuskan untuk dilanjutkan pada siklus II, dengan memperhatikan setiap kelemahan pada siklus I, baik untuk guru maupun siswa. Hal-hal yang harus diperhatikan adalah guru perlu menguasai RPP, guru harus memberikan motivasi dan bimbingan secara merata kepada siswa, pengelolaan waktu harus secara maksimal oleh guru.

Pada siklus II, Metode Pembelajaran CIRC (Cooperative Integrated Reading and Composition) berbasis herbarium, kembali dilaksanakan. Berdasarkan hasil observasi pada tindakan siklus II, kegiatan guru dalam melaksanakan proses pembelajaran telah meningkat. Kekurangan-kekurangan yang terjadi pada siklus I sudah dapat diperbaikisedikit demi sedikit. Pada tindakan siklus II, guru telah melakukan Metode Pembelajaran CIRC (Cooperative Integrated Reading and Composition) berbasis herbarium, berdasarkan RPP Yang ada dengan mengaitkan materi yang dipelajari dengan kehidupan disekitar siswa. Selanjutnya, siswa duduk dalam kelompok untuk berdiskusi, meskipun ada sebagian siswa yang lebih memilih diam dari pada aktif dalam kelompok. Guru mulai terbiasa dengan model pembelajaran yang diterapkan, guru sudah mulai, memberikan motivasi kepada siswa, namun masih 
sebatas memberikan dorongan pada siswa yang belum aktif. Guru sudah mampu mengelola waktu dengan baik, meskipun ada beberapa session yang panjang.

Secara umum siklus II dapat dikatakan sudah mengalami peningkatan, hal ini terlihat dari hasil observasi siswa dalam kelompok dan hasil observasi guru dalam proses pembelajaran sudah berjalan dengan baik. Bahkan berdasarkan hasil tes akhir siklus II menunjukan bahwa sebanyak 29 siswa atu sebesar $84 \%$ siswa yang memperoleh presentase nilai $>75 \%$. Ini menunjukan pelaksanaan tindakan pada siklus II telah mencapai hasil yang baik dalam meningkatkan hasil belajar siswa. Hal ini dilihat dari hasil observasi untuk guru dan siswa, serta hasil tes akhir yang mencapai criteria ketuntasan yang telah ditetapkan. Dengan mempertimbanghkan hasil yang diperoleh, maka diputuskan bahwa pembelajaran tidak dilanjutkan pada siklus III.

Berdasarkan hasil angket siswa yang dianalisis oleh peneliti, guru dan teman sejawat, menunjukan bahwa siswa sangat merespon dengan baik penggunaan Metode Pembelajaran CIRC (Cooperative Integrated Reading and Composition) berbasis herbarium untuk meningkatkan hasil belajar pada konsep tumbuhan paku.

Karena indicator keberhasilan dalam penelitian telah dicapai dalam hal ini $84 \%$ siswa telah mencapai presentasi pencapaian $65 \%$ maka penelitian ini dihentikan pada siklus II. Ini berarti hipotesis tindakan telah tercapai, yaitu melalui penggunaan Metode Pembelajaran CIRC (Cooperative Integrated Reading and Composition) berbasis herbarium, hasil belajar konsep tumbuhan paku pada siswa kelas X SMA Negeri Bojonegoro dapat ditingkatkan. Untuk menjamin keasahan data penelitian ini, melakukan triangulasi pada setiap siklus, yaitu pemeriksaan keabsahan data dengan membandingkan hasil tes dan hasil observasi yang telah diperoleh dari setiap tindakan yang telah dilakukan.

\section{SIMPULAN}

Setelah peneliti cermati dalam kegiatan penelitian kelas dari proses sampai hasil, maka peneliti menyimpulkan bahwa metode Pembelajaran CIRC (Cooperative Integrated Reading and Composition) berbasis herbarium, maka hasil belajar biologi siswa dapat ditingkatkan. Hal ini terlihat dari hasil tes awal mencapai $24 \%$ hasil tes akhir siklus I mencapai $52 \%$, pada siklus II meningkat menjadi $85 \%$. Dari hasil angket siswa terhadap pendekatan herbarium yan digunakan pada konsep tumbuhan paku menunjukan bahwa sebagian besar siswa sangat setuju pembelajaran ini menggunakan Metode Pembelajaran CIRC (Cooperative Integrated Reading and Composition) berbasis herbarium.

\section{DAFTAR PUSTAKA}

Abdurrahman. 1999. Pendekatan bagi Anak Berkesulitan Belajar. Jakarta:

Rhineka Cipta.

Arikunto. 2006. Belajar dan Pembelajaran. Jakarta: Rhineka Cipta.

Arikunto. S. 2001. Prosedur Penelitian Suatu Pendekatan Praktek. Jakarta: Rhineka Cipta.

Aryulina, 2006. Biologi untuk kelas X. Buku Eshis, Jakarta 
Ati, A. P., Widiyarto, S., \& Suyana, N. (2018). Penerapan Metode Picture And Picture Untuk Peningkatan Keterampilan Menulis Narasi Pada Siswa Kelas VIII SMP Al Ihsan Dan SMP Tashfia Kota Bekasi. Adimas: Jurnal Pengabdian Kepada Masyarakat, 2(1), 30-36.

Alifah, S., Narsih, D., \& Widiyarto, S. (2019). Pengaruh Metode Partisipatori Dan Minat Belajar Terhadap Kemampuan Berwirausaha Siswa Smk. Lectura: Jurnal Pendidikan, 10(1).

Irawadi, M. H., Martha, I. N., \& Wendra, I. W. (2015). Penerapan Model Pembelajaran Cooperative Integrated Reading and Composition (CIRC) Untuk Meningkatkan Hasil Belajar Siswa Dalam Menulis Karya IImiah Di Kelas XII AP I SMK Negeri 1 Seririt. Jurnal Pendidikan Bahasa dan Sastra Indonesia Undiksha, 3(1).

Juita, H. R., \& Widiyarto, S. (2019, March). The Effectiveness of Cooperative Learning Methods: A case study of writing learning at Junior High School. In Second Conference on Language, Literature, Education, and Culture (ICOLLITE 2018). Atlantis Press.

Lawi, S., \& Putra, S. H. J. (2020). Efektivitas Model Pembelajaran Problem Based Learning dan Number Head Together Terhadap Keterampilan Proses Sains dan Hasil Belajar Siswa Kelas VII SMP Santa Maria Maumere. Spizaetus: Jurnal Biologi dan Pendidikan Biologi, 1(2).

Manurung. M. 2008. Penelitian Tindakan Kelas. Jakarta: Gramedia Widya sarana Indonesia

Onrizal. 2005. Teknik Pembuatan Hebarium. http://ocw.usu.ac.id. Diakses pada tanggal 12 Februari 2013.

Tjitrosoepomo, G. 2007. Morfologi Tumbuhan. Gajah Mada University Press Yogyakarta.

Sumarwan. 2006. Mengenal tumbuhan paku. www.tumbuhanpaku.com.diakses 12 Februari 2013

Widiyarto, S. (2017). Pengaruh Metode Student Teams Achievement Division (STAD) dan Pemahaman Struktur Kalimat terhadap Keterampilan Menulis Narasi. Lectura: Jurnal Pendidikan, 8(1). 